Jurnal Akuntansi \& Perpajakan, Volume 1, No. 2, Januari 2020

\title{
THE ROLE OF ITGC IN SUPPORTING FINANCIAL AUDIT
}

\author{
Adrian $^{1}$, Sakthy Yudha Santri ${ }^{2}$ \\ Sekolah Tinggi Ilmu Ekonomi Jayakarta \\ atjitranov@gmail.com, sakhtyyudhasantri5001@gmail.com
}

\begin{abstract}
ITGC (Information Technology General Control) is generally known as part of the Financial Audit conducted by the External Auditor. Very diverse software from small scale to enterprise class is needed for many companies due to the rapid development of the business. For the external auditors themselves, one of the jobs performed is to conduct regular financial audits in accordance with the needs of their clients. The regulators themselves both OJK and BI as well as other fields in accordance with their business such as BAPEPAM, have also required several regulations that must be considered by each company that uses information technology in supporting its business
\end{abstract}

Keywords: ITGC, Regulator, Information Technology, Financial Audit

\section{PERANAN ITGC DALAM MENDUKUNG AUDIT FINANSIAL}

\begin{abstract}
ABSTRAK
ITGC (Information Technology General Control) secara umum sudah dikenal sebagai bagian dari Audit Keuangan yang dilakukan oleh pihak Auditor External. Perangkat lunak yang sangat beragam dari skala kecil hingga kelas enterprise bagi banyak perusahaan sangat dibutuhkan dikarenakan perkembangan dari bisnisnya yang sangat pesat. Bagi pihak Auditor eksternal sendiri salah satu pekerjaan yang dilakukan adalah melakukan audit keuangan secara regular sesuai dengan kebutuhan klien mereka. Pihak regulator sendiri baik OJK maupun BI serta bidang lain sesuai dengan bisnisnya seperti BAPEPAM, juga telah mensyaratkan beberapa regulasi yang harus diperhatikan oleh masing-masing perusahaan yang menggunakan teknologi informasi dalam mendukung bisnisnya.
\end{abstract}

Kata-kata Kunci: ITGC, Regulator, Teknologi Informasi, Audit Finansial

Korespondensi: Adrian, SKom, MMSI. STIE Jayakarta, Jalan Salemba I No.10, RT.4/RW.6, Jakarta 10430. Email: atjitranov@gmail.com 
Jurnal Akuntansi \& Perpajakan, Volume 1, No. 2, Januari 2020

\section{PENDAHULUAN}

Audit keuangan tentunya merupakan salah satu persyaratan yang harus dilakukan oleh semua perusahaan baik yang sudah masuk ke bursa saham maupun yang masih dikelola oleh internal perusahaan sendiri.

Beberapa kasus baik didalam atau luar negeri,menunjukan bahwa seluruh laporan keuangan harus dapat dibuktikan ke akurasian datanya, baik yang bersumber dari data yang diolah secara konvensional maupun menggunakan teknologi informasi.

Pengendalian sistem informasi terkait dengan data nasabah, keakurasian jurnal piutan pembiayaan dan pemerolehan bukti audit yang cukup dan tepat atas akun piutang pembiayaan konsumen yang terjadi pada kasus audit laporan SNP Finance pada tahun 2018 oleh afiliasi Deloitte Indonesia, maupun yang terjadi pada tahun 2019 untuk laooran keuangan Garuda Indonesia, serta kasus di Amerika Serikat yaitu periode ahun 2000 - 2002 terhadap laporan keuangan Enron yang merupakan salah satu perusahaan terbesar di Amerika Serikat, dimana terjadi sejumlah transaksi kompleks yang memungkinkan pihak Enron untuk menyembunyikan utang-utangnya. Sehingga setiap perusahaan yang menggunakan sistem maupun tidak perlu melakukan assestment terhadap seluruh prosedur terutama yang mendatangkan pendapatan (revenue) bagi perusahaan.

\section{METODE}

Metode yang digunakan adalah metode pustaka, best practice dan dokumentasi publikasi Internet.

\section{PEMBAHASAN}

Sebelum dilakukan pembahasan mengenai Audit Teknologi Informasi akan dijelaskan perbedaan antara Sistem Informasi dengan Teknologi Informasi. Dalam Sistem Informasi ada 3 komponen yaitu People, Process dan Technology (Teknologi Informasi - TI) yang dikobinasikan dalam sttrategi, manajerial dan aktivitas operasional terkiat dengan pngelolaan informasi. Dalam Sistem Informasi melibatkan perangkat keras (hardware), perangkat lunak (software), jalur komunikasi, serta komponen TI yang terkait lainnya seperti input data, penyimpanan data, pemrosesan data, komunikasi data dan data output) Gambar 1 menunjukkan perbedaan antara Sistem Informasi (SI) dan Teknologi Informasi (TI)

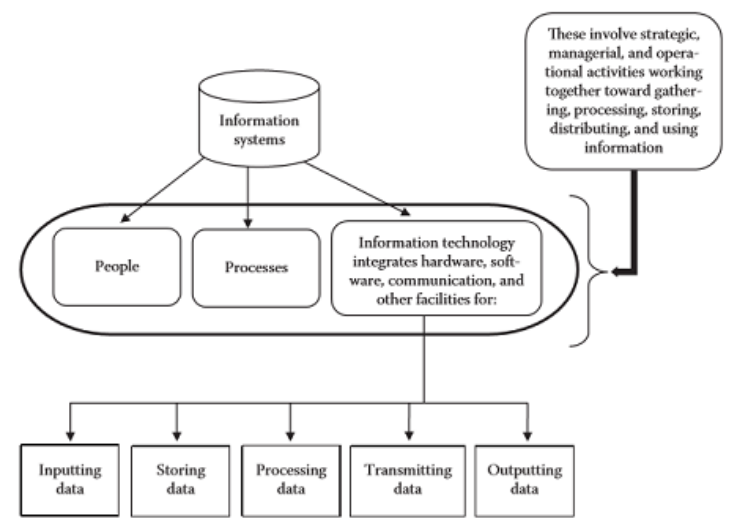

\section{Gambar 1}

Sistem Informasi vs Teknologi Informasi Sumber: COBIT (2019) 
Jurnal Akuntansi \& Perpajakan, Volume 1, No. 2, Januari 2020

Definisi Audit menurut ISACA menunjukkan kegiatan pemeriksaan secara formal dan verifikasi untuk mengecek kesesuaian dengan standard atau sejumlah aturan yang diikuti, keakurasian data atau efesiensi dan efektifitas sesuai dengan target yang dicapai.

Audit TI diperlukan untuk mengevaluasi kesesuaian sistem aplikasi yang memenuhi kebutuhan pemrosesan, evaluasi terhadap kesesuaian kontrol internal, dan memastikan bahwa aset yang dikendalikan oleh sistem tersebut dilindungi dengan memadai.

Ada dua kelompok audit TI, yang keduanya untuk memastikan beroperasinya Sistem Informasi, yaitu :

(1) General Computer Control Audit atau IT General Control "ITGC" pengendalian umum terhadap TI, dimana melakukan pengawasan secara umum terhadap kebijakan dan prosedur yang terkait dengan sejumlah aplikasi dan mendukung berfungsinya pengendalian aplikasi secara efektif. Pengawasan umum ini mencakup infrasruktur TI dan layanan dukungan, termasuk semua system dan aplikasi yang digunakan.Pengawasan umum mencakup :

(a) Operasional SI

(b) Keamanan Informasi

(c) Pengendalian manajemen perubahan (pengadaan sistem perangkat lunak perubahan dan pemeliharaan sistem aplikasi
Contoh pengendalian umum dalam operasional SI menangani kegiatan seperti pencadangan (backup) data dan penyimpnan diluar lokasi, pengawasan terhadap job terjadwal (job scheduling) dari sistem aplikasi yang digunakan.

Contoh pengawasan umum terhadap keamanan informasi seperti pengelolaan terhadap permintaan akses dan administrasi akun dari Sistem, penghentian akses dan keamanan secara fisik.

Contoh pengendalian manajemen perubahan, mencakup perubahan persetujuan permintaan, perubahan di aplikasi dan basis data dan pemantauan infrastruktur jaringan, keamanan dan majaemen perubahan.

(2) Application Control Audit -Pemeriksaan terhadap pe-ngendalian aplikasi. Kegiatan pemeriksaan ini khusus terhadap aplikasinya, Pengendalian aplikasi ini disebut juga sebagai "Automated Controls - kontrol otomatis" Hal ini berkaitan dengan keakurasian, ke-lengkapan, validitas dan otorisasi data yang diperoleh, dimasukkan, diproses, disimpan, dikirim dan yang dilaporkan.

Contoh kontrol aplikasi termasuk memeriksa keakurasian per-hitungan, memvalidasi data input, dan melakukan pe-meriksaan terhadap sejumlah per-hitungan numerik. Kontrol aplikasi cenderung efektif ketika kontrol umum efektif. 
Jurnal Akuntansi \& Perpajakan, Volume 1, No. 2, Januari 2020

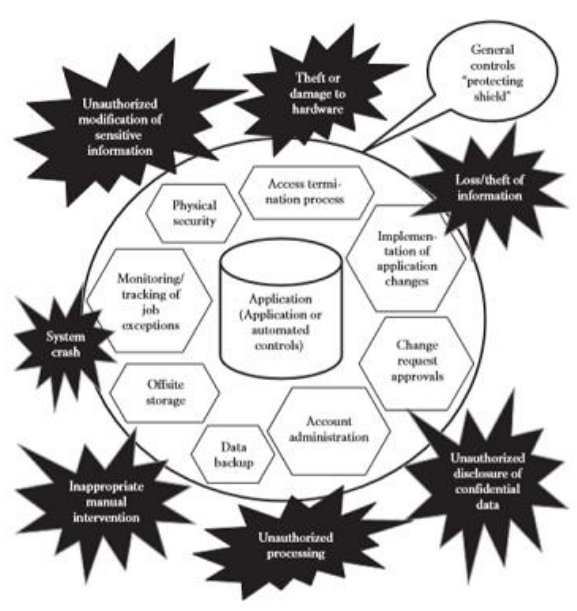

Gambar 2. Hubungan antara General Computer Control dan Application Control

Sumber : COBIT (2019)

Gambar 2 merupakan ilustrasi dari ITGC dan Application Control dan bagaimana pengendalian resiko yang dapat ditimbulkan. Resiko dapat disebabkan oleh beberapa hal seperti akses yang tidak sah, kehilangan atau pencurian terhadap informasi, termasuk juga perlindungan langsung atas input, pemrosesan dan output informasi.

Secara umum pihak auditor (Kantor Akuntan Publik - KAP) akan menggunakan tools (alat bantu) sebagai assestment workbook lembar kerja yang digunakan untuk kegiatan auditnya.

Apabila pihak tim auditor menemukan sistem yang digunakan sangat kompleks yang ditandai dari jenis aplikasinya, yang sudah berbasis Enterprise (ERP) maka kegiatannya akan dilakukan oleh tim IT (IT expert), namun apabila sederhana dapat dilakukan sendiri oleh tim Financial Auditor.
Sedangkan untuk Application Control dilakukan apabila ingin pengujian lebih mendalam terhadap sistem yang digunakan di perusahaan yang akan diaudit.

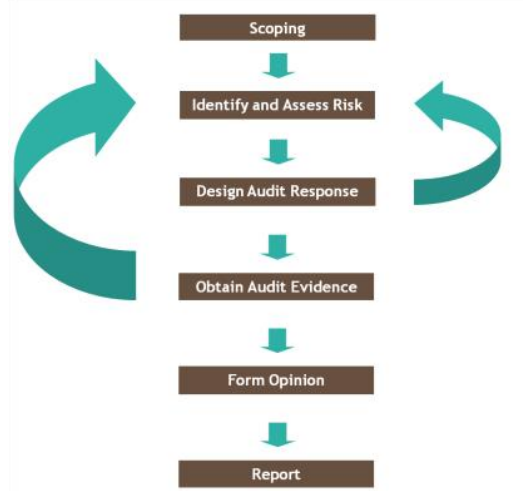

\section{Gambar 3. Contoh Metodelogi ITGC} Sumber: E-learning ITGC (2016)

Gambar 3 menggambarkan tahapan proses yang dilakukan dalam tahapan ITGC, yaitu :

Implementasi ITGC secara umum menjadi prasyarat wajib apabila pihak perusahaan yang akan diaudit menggunakan Teknologi Informasi dalam pengolahan datanya

(a) Scoping, menentukan ruang lingkup pekerjaan, yang dikategorikan atas :

(a) Logical Access Control (User Account Management), hal mengenai bagaimana prosedur yang mengenai hak akses user, password policy, pembagian wewenang dan history log dalam sistem.

(b) Program Change Control, hal mengenai bagaimana prosedur yang digunakan apabila ada mekanisme perubahan terhadap sistem, termasuk keterlibatan dengan pihak pemasok. 
Jurnal Akuntansi \& Perpajakan, Volume 1, No. 2, Januari 2020

(c) Automated Process or Interface (jika diterapkan), apabila dalam sistem terhadap proses batch, atau proses terjadwal lainnya perlu dideskripsikan termasuk mekanisme dalam prosedurnya.

(d) Data/System Migration (jika diterapkan), bagaimana prosedur yang dilakukan apabila terjadi migrasi dari sistem lama ke sistem baru, termasuk mekanisme pengujian dan tim yang terlibat.

(2) Identify and Assess Risk, melakukan identifikasi dan penilaian resiko), yang dilakukan melalui :

(a) Review terhadap dokumen (kebijakan, prosedur dan dokumen terkait)

(b) Wawancara atau diskusi

(c) Pengamatan (Observasi)

Gambar 4 merupakan salah satu contoh pertanyaan yang diajukan ke perusahaan yang akan diaudit untuk menggambarkan kondisi internal perusahaan dan tata kelola yang ada

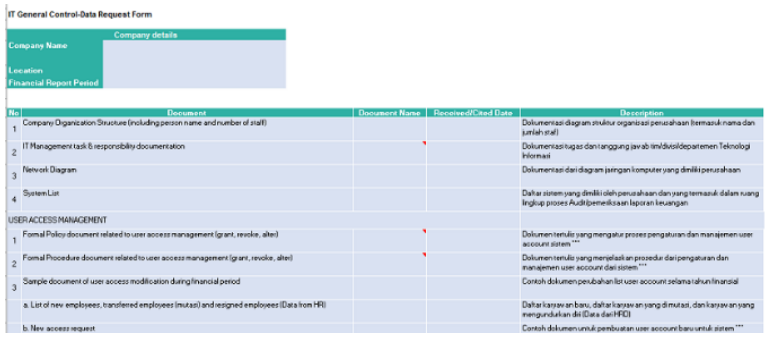

Gambar 4. Contoh Assestment ITGC Sumber: E-learning ITGC (2016)

(3) Design Audit Response, melalui tahapan Analisa ini dilakukan interaksi dengan pihak client.
(4) Obtain Audit Evidence, pada tahapan ini dilakukan beberapa Analisa yang dituangkan pada assestment workbook yang digunakan (Gambar 5)

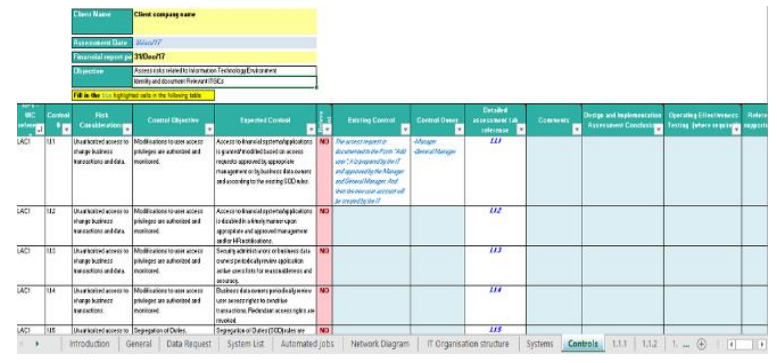

\section{Gambar 5. Assesment Workbook}

Sumber: E-learning ITGC (2016)

(5) Form Opinion, tahapan ini memberikan beberapa opini temuan yang menjadi dasar pembuatan report.

(6) Report, pembuatan laporan ini bertujuan untuk memberikan gambaran terhadap perusahaan yang di audit, jika ditemukan adanya kekurangan terutama pada tata kelola maka diberikan rekomendasi agar dilakukan perbaikan dimasa yang akan datang. Gambar 6 contoh report yang dihasilkan yang akan dilampirkan sebagai pelengkap dari laporan audit keuangan.

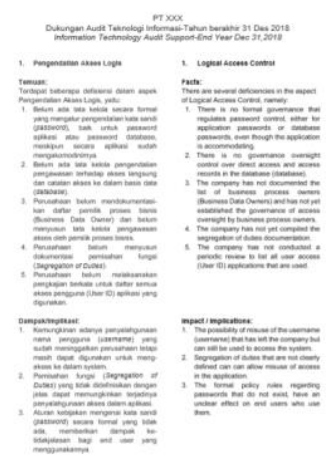

Gambar 6. Report ITGC Sumber: E-learning ITGC (2016) 
Jurnal Akuntansi \& Perpajakan, Volume 1, No. 2, Januari 2020

\section{KESIMPULAN}

Penggunaan Teknologi Infomasi bagi semua perusahaan dalam pengolahan data terutama yang memberikan revenue, menjadi salah satu hal yang diperhatikan oleh pihak auditor eksternal yang melakukan kegiatan Audit Keuangan.

Regulasi dari pemerintah baik oleh Otoritas Jasa Keuangan (OJK), maupun Bank Indonesia serta regulator yang terkait dengan kebijakan sesuai dengan bidang usaha, telah menetapkan sejumlah aturan yang wajib ditaati dan perhatikan, seperti aturan OJK mengenai keharusan memiliki ISO 270001 untuk perusahaan bergerak dibidang Fintech (Finance Technology), peraturan OJK No 38 /POJK.03/2016 mengenai penerapan manajemen resiko dalam penggunaan teknologi informasi oleh Bank Umum.

Secara umum perusahaan yang telah dilakukan audit memiliki beberapa kekurangan pada tata kelola (prosedur) yang belum dimiliki, meskipun secara aplikasi telah sesuai dengan standar pemeriksaan, seperti password policy, terdapat $\log$, pemisahan wewenang pada modul aplikasi.

Hal yang harus diperhatikan oleh setiap auditor terutama apabila perusahaan yang diaudit menggunakan aplikasi pastikan bahwa informasi yang dihasilkan sesuai (valid) dengan melakukan pengamatan secara langsung atau melakukan pengujian dengan skenario data.

\section{DAFTAR PUSTAKA}

Cannon, David L (2008), CISA Certified Information System Auditor, Study Guide, Second Edition, Wiley Publishing, Inc

E-learning Basic Of IT General Controls (ITGCs), (2016), BDO

ITGC Risk (Februari 2020) diakses dari https://www2.deloitte.com/content/dam/Deloitte /in/Documents/risk/i-ra-general-it-controlsnoexp.pdf

Kasus Garuda (Febrauri 2020) diakses dari https://www.cnnindonesia.com/ekonomi/201904 30174733-92-390927/kronologi-kisruh-laporankeuangan-garuda-indonesia

Kasus Skandal Enron (Februari 2020) diakses dari https://www.thebalancesmb.com/sarbanesoxley-act-and-the-enron-scandal-393497

Kasus SNP Finance (Februari 2020) diakses dari https://www.cnbcindonesia.com/market/201808 30074647-17-30904/kasus-snp-finance-srimulyani-hukum-deloitte-indonesia

LanteR, David. (2018), COBIT 2019 Framework : Introduction and Methodology, ISACA

Otero, Angel R. (2018), Information Technology Control and Audit, Fift Edition, CRC Press. 